IZA DP No. 4776

Wage Work for Women:

The Menstrual Cycle and the Power of Water

Yasheng Maimaiti

W. S. Siebert

February 2010

Forschungsinstitut zur Zukunft der Arbeit Institute for the Study of Labor 


\title{
Wage Work for Women: The Menstrual Cycle and the Power of Water
}

\author{
Yasheng Maimaiti \\ University of Birmingham \\ W. S. Siebert \\ University of Birmingham \\ and IZA
}
Discussion Paper No. 4776
February 2010

\author{
IZA \\ P.O. Box 7240 \\ 53072 Bonn \\ Germany \\ Phone: +49-228-3894-0 \\ Fax: +49-228-3894-180 \\ E-mail: iza@iza.org
}

Any opinions expressed here are those of the author(s) and not those of IZA. Research published in this series may include views on policy, but the institute itself takes no institutional policy positions.

The Institute for the Study of Labor (IZA) in Bonn is a local and virtual international research center and a place of communication between science, politics and business. IZA is an independent nonprofit organization supported by Deutsche Post Foundation. The center is associated with the University of Bonn and offers a stimulating research environment through its international network, workshops and conferences, data service, project support, research visits and doctoral program. IZA engages in (i) original and internationally competitive research in all fields of labor economics, (ii) development of policy concepts, and (iii) dissemination of research results and concepts to the interested public.

IZA Discussion Papers often represent preliminary work and are circulated to encourage discussion. Citation of such a paper should account for its provisional character. A revised version may be available directly from the author. 
IZA Discussion Paper No. 4776

February 2010

\section{ABSTRACT Wage Work for Women:
The Menstrual Cycle and the Power of Water}

We hypothesise that women's participation in wage (off-farm) work is reduced when their greater water needs due to the menstrual cycle are not met because their household has poor access to water. For testing, we use the data from rural villages in China. Controlling for village fixed effects, poor access to water is found to decrease the probability of wage work participation of affected (pre-menopause) women by about 10 percentage points, a large effect. As expected, there is no adverse causal impact of poor household access to water for women post-menopause, or for men, ceteris paribus.

\section{NON-TECHNICAL SUMMARY}

In this study, we investigate the impact of poor access to water on women's wage work participation in rural China. This study hypothesises that women pre-menopause face higher costs of participation and achieve lower productivity when access to water is poor (holding other things equal), and therefore have lower rate of wage work participation. We use the China Health and Nutrition Survey dataset for 1993 to test the hypothesis. In this dataset, about half of the respondents do not have access to improved water, and also a large number of respondents are not involved in any type of wage work. Most importantly, there is specific information about women's menopause status. We use both regression analysis and Propensity Score Matching methods to test the hypothesis. Both approaches yield supportive results. Women pre-menopause are found to be especially affected by poor access to water, that is, their probability of participating in wage work is about 10 percentage points lower than their peers with good access to water controlling for other confounding factors. For men, and for women post-menopause, poor access to water per se has no causal impact on wage work participation. Therefore, a major benefit of policies to improve water supplies may not be the obvious household or industrial benefit, but rather an unseen benefit, the improvement in the working position of women. While much of these benefits have already been gained in China which has made good progress in raising access to water, the results should be relevant to other areas of the developing world.

JEL Classification: J16, J21, O15

Keywords: $\quad$ wage work, women, menopause, water engineering, rural development, China

Corresponding author:

W. S. Siebert

Birmingham Business School

University House

Edgbaston

Birmingham B15 2TT

United Kingdom

E-mail:w.s.siebert@bham.ac.uk 


\section{Introduction}

In the developing world, women's participation in wage work (off-farm work) falls well behind that of men, reducing women's income (Zhang et al, 2002, 2004), and women's reproductive health (Stewart et al 2004, Wang 2007). There are also important implications for society and democracy. Lack of employment outside the home reduces women's participation in the political system (Burns, 1997; Chhibber, 2002), which feeds back into less concern for women's education, and perhaps a less secure democracy given the link (Glaeser et al, 2007) between education and democracy. Indeed, increasing the proportion of women in wage employment in the non-agricultural sector is now one of the United Nation's millennium development goals to empower women (UN, 2009).

This paper starts from the observation that women fall behind particularly when the household has poor access to water. Figure 1 demonstrates this fact, using a cross-country dataset. Moreover, menstrual health problems are reported to be more pronounced for women with poor hygiene facilities (Ahmed and Yesmin, 2008) or who experience stress (Deuster et al., 1999) which can be linked to poor access to water. Building on these observations, we hypothesise that where there is a lack of tap water for women to wash during the menstrual cycle, they will find it more difficult to be hired for, and succeed in, wage work. Water engineering might therefore have a role in advancing not only women's education and health, but also their incomes, and ultimately their wider participation in society.

Variables relating to the menstrual cycle, and to water supply, have only recently begun appearing in economic analysis. In studies of education, following the development literature (e.g., Bharadwaj and Patkar, 2004) the onset of menstruation (menarche) is increasingly seen as playing a role in explaining rural girls' low schooling attainment (but for contrary evidence see Oster and Thornton, 2008). Possible avenues are that menarche pushes elder sisters into early marriage (Field and Arbus, 2008), or alternatively that it interacts with lack of water to raise girls' schoolgoing costs (see Maimaiti and Siebert, 2009). Goldin and Katz's (2002) work on the role of the pill in expanding women's higher education is also noteworthy. Beyond the economics of education there has been little economic interest, though Ichino and Moretti (2009) have recently used the menstrual cycle variable to explain women's absenteeism (see also Chawla et al, 2002).

Lack of a water supply, for its part, is obviously important for studies of health (e.g., Wateraid, 2008), and there is a growing health economics literature (e.g., Galiani et al 2005 and 2009, Mangyo 2008). It is seen also as important for economic development in general, and sustainable access to safe drinking water is again a UN Millennium target (UN, 2009). But in studies of wage work opportunities for women (e.g., Hare, 1999; Zhang 2002) the possibility of a particular adverse effect for women of lack of water has not been explored until now. The typical study of course includes local economic development variables and village fixed effects to pick up the regional economic environment which will influence wage work opportunities for both men and women. However, general regional environment variables may fail to pick up the peculiar adverse impact of poor access to water on women, our focus. 
The data we use for testing relate to China, because the Chinese Health and Nutrition Survey (CHNS) provides a good dataset, not because China currently has particular problems either with poor water or with women lagging in wage work. Our aim is to estimate effect magnitudes, which hopefully will be applicable to the many developing countries where women are disadvantaged. The CHNS is a nationally representative dataset which has specific information on household access to tap water as well as information on women's menopause status (though only in wave 1993), and is therefore well suited to test our hypotheses.

\section{The Hypothesis}

The following quotation gives an idea of the problems that women without good water access face. Clearly in these circumstances, engaging in responsible wage work will be difficult.

"Women and girls in poor countries cannot afford sanitary pads and tampons ... Instead the vast majority of women and girls in Bangladesh use rags. These are usually torn from old saris and known as 'nekra'... there is no private place to change and clean the rags and often no safe water and soap to wash them properly ... This practice is responsible for a significant proportion of illness and infection..." (Ahmed and Yesmin, 2008, 284)

Our study hypothesizes that, on the supply side, poor access to water poses special costs of wage work involvement for women pre-menopause. The problem is the increased time, health and psychic costs associated with the menstrual cycle in poor water circumstances, as shown in the quotation (in the related context of girls' education see also Burrows et al 2004, and Kirk and Sommer 2006). These costs imply a higher wage (compensation) will be required to undertake a given job.

On the demand side, menstruation-related poor health and pain cause higher absence (Ichino and Moretti, 2009; Dean et al, 2004), and lower productivity even in good water circumstances. In bad circumstances (Deuster et al 1999), the consequences are greater. Hence we would expect reduced labour demand for women with adverse backgrounds. Thus demand and supply side factors both point to premenopause women with poor access to water having lower wage work employment.

There are further implications of the hypothesis for post-menopause women and for men. For both these groups, the menstruation-related impact of poor access to water on wage work involvement cannot exist. Hence, both these groups can provide a baseline against which to assess this impact. Admittedly, both groups have their problems as comparators. There is not much age overlap between pre- and postmenopause women, which makes for difficulties in controlling for age and homework responsibilities. The comparison with men suffers because men might be generally advantaged in the workforce - and have fewer home responsibilities. Nevertheless, the comparisons have some utility since we would expect that, for these groups, adequate allowance for local poverty and lack of development should eliminate any separate effect of poor access to water on opportunities for wage work. 


\section{Data and variables}

The research context for this study is rural China. This setting provides suitable conditions to test the hypothesis. First, a considerable number of households did not have access to tap water in rural China in our survey year, 1993. Figure 2 gives the proportion of households which have access to different types of water in rural China for the sample. As can be seen, in 1993, about 50\% of the households did not have access to tap water (either in-house and in-yard). Access to tap water is the conventional standard (Jalan and Ravallion, 2003), which we adopt. Second, there is a good opportunity to participate in rural wage work thanks to China's economic reforms - about 1/3 of total rural labour force in the 1990s were engaged in wage work (Sicular and Zhao, 2004, 241). Hence there are good sample sizes in all categories.

As noted above, we use the CHNS which is jointly conducted by the University of North Carolina and the Chinese Academy of Preventive Medicine, Beijing. The CHNS is designed to examine "how the social and economic transformation of Chinese society and family planning programs implemented by national and local government affect the economic, health and nutritional status of its population" (CHNS, 2007). From the CHNS we form a 1993 dataset with information for men and women aged 16-60 from 128 rural sites ("rural" for individual respondents being defined according to household registration) in 8 provinces. These provinces stretch from the North-East to the South-West, and vary substantially in geography and economic development (Yang, 2006), which provides good variation and representative coverage of a large part of China.

Our work is most closely related that of Hare (1999) and Zhang et al (2002) who also investigate determinants of the wage work status in China. Following Hare (1999), we construct a 'wage work participant' status dummy variable depending upon whether the respondent has been involved in wage work activity as an employee during the last 12 months. (Note, we include all self-employed in the non-wage work category.) The relevant percentages, by household water access, are given in Table 1: As can be seen, men in general participate more in wage work than women, and wage work (see memo items in the bottom rows) pays much better than farm work. Also good household access to water is correlated with more wage work, for both sexes, presumably because of the better economic environment in which household with good water access find themselves. Thus, the village average off-farm employment rate is $50 \%$ in good access to water areas, and only $22 \%$ in poor access areas. Moreover, individuals, both male and female, are better educated in the good access to water categories, indicating a sorting of the more productive workers into the more productive areas.

However, following our hypothesis, note the bigger impact of poor access to water for the pre-menopause women, 23 percentage points $(=36-13)$ than for postmenopause women, 6 percentage points $(=9-3)$, or men, 20 points $(=43-23)$. This difference in difference analysis can be pursued using Table 2, pointing to a possible role for menopause in explaining the impact of poor access to water, though of course local economic development which is correlated with poor access to water must be controlled. 
The control variables included in the regression, apart from access to water and menopause, are similar to those used in (Hare, 1999 and Zhang et al., 2002). The respondent's educational qualifications and age are included as measures of human capital which act as proxy for the expected wage offer. Family structure variables are also included to allow for supply side effects on wage work participation. Under this heading come marital status, the number of elderly people over 60 who are present in the home, and numbers of children present in the home. Some of these variables can be expected to affect women pre- and post-menopause, and men, differently, and so cross-products will be required. Also included in the regression is land owned per family adult member, which will affect alternatives to wage work.

Judging by the statistics shown in Table 1, poor access to water is likely to be associated with backward geographical location and a generally unfavourable village environment. These factors may generate a "culture" unfavourable to women (for example see Song et al 2006). To tackle this problem, we control for the proportion of off-farm employment in the village. As a further control, we include 128 village dummies, converting the analysis to a within-village analysis. "Culture" effects will thus have to be interpreted as applying to only part of a village, which is possible, but less likely.

A further problem is that unobserved individual characteristics (e.g., an active attitude for hygiene and work) may be positively correlated with wage work participation and access to good water. This linkage would cast doubt on the exogeneity of access to tap water, raising the need for instrumentation. In fact, we find that government investment in village water construction (variable water plant hereafter) is a good instrument - well correlated with the probability of a household having access to tap water, but not directly linked to an individual's wage work participation. We therefore have a reasonable basis to test for endogeneity.

\section{Empirical Strategies}

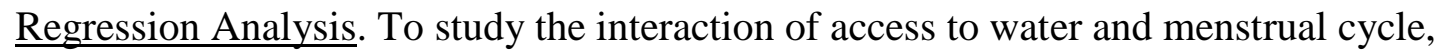
we use a difference-in-difference specification:

$$
Y_{i}=\beta_{1}+\beta_{2} W_{i}+\beta_{3} M_{i}+\beta_{4} W_{i} \times M_{i}+\beta_{5} X_{i}+\varphi_{s}+\varepsilon_{i}
$$

where $i$ denotes individuals; $Y_{i}$ is an indicator for having participated in any wage work during the last 12 months; $X_{i}$ is a vector of controls for individual and household characteristics; $W_{i}$ is an indicator equal to one if the household has no access to tap water; $M_{i}$ is an indicator equal to one if the individual is pre-menopause; $\varphi_{s}$ is a full set of 128 village dummies (for small samples, 36 county dummies); and $\varepsilon_{i}$ is the error term.

$\beta_{4}$ is the coefficient of interest. We expect poor access to water to have a more adverse impact on pre-menopause women's wage work participation, due to the hygiene/time/psychic related menstrual problems they face as described earlier. These considerations point to a negative interaction between the access to water and menstrual cycle. The adverse impact of poor access to water on pre-menopause women $\left(\beta_{2}\right)$ is expected to be small or zero. In order to allow full variation of the impacts of the other control variables, we also estimate probit models for these two groups of women separately. In this case, for pre-menopause women we have:

$$
Y_{i}=\left(\beta_{1}+\beta_{3}\right)+\left(\beta_{2}+\beta_{4}\right) W_{i}+\beta_{5} X_{i}+\varphi_{s}+\varepsilon_{i}
$$


showing that the coefficient on $W$ is the sum of both $\beta_{2}$ and $\beta_{4}$, while for postmenopause women we have simply:

$$
Y_{i}=\beta_{1}+\beta_{2} W_{i}+\beta_{5} X_{i}+\varphi_{s}+\varepsilon_{i}
$$

Thus, we can recover $\beta_{4}$ simply by comparing the coefficient on $W$ in the two regressions.

After estimating the probit coefficients, we calculate average marginal effects (AME) of the regressors since estimating the AME is recommended for policy analysis (Cameron and Trivedi, 2009, 340). (Where there are many cross-products, however, we simply give the raw probit coefficients (see Bartus 2005), since AME are then misleading.) The AME may also be more comparable to the average treatment on the treated (ATT) that is to be obtained in the second phase of this research via Propensity Score matching techniques, since both of these measure average effects of a treatment on those who received the treatment.

Propensity Score Matching. Regression analysis provides a complete mechanism to analyse treatment effects, but only in ideal circumstances, and Propensity Score Matching (PSM) (see Caliendo and Kopeinig, 2008; Imbens and Wooldridge, 2009) might be more robust. In the regression case, a full model is estimated which gives a check on the plausibility of the model as a whole, and on effect sizes for many variables of interest. On the other hand, selection bias needs to be tackled by including all 'necessary' variables in the regression as controls (the so called 'long model') and appropriate instrumentation (see Angrist and Pischke, 2009), which is obviously difficult to do.

PSM works by making the assignment of the poor access to water "treatment" random between the comparison groups. A 'score' based on a logit determining poor access to water is estimated for all individuals in the sample. This 'propensity score' is the conditional probability of receiving the poor access to water treatment given pre-treatment characteristics (Rosenbaum and Rubin, 1983). The sample is then separated into about five different blocks or strata (Imbens and Wooldridge, 2009, 33) according to the propensity scores so that within each block the propensity score is essentially constant and the data can be taken as coming from a randomised experiment. The effect of the treatment is then identified within each block and the average taken across blocks to give the average treatment effect on the treated (ATT).

PSM reduces the effect of unobserved, possibly endogenous (see Frolich, 2008), factors causing differences between treated and controls by accurate matching (but for a warning see Pearl, 2009). Matching is assisted by the blocking technique noted above, and also via the "common support" requirement. This requirement involves dropping individuals in the treatment group who have a probability of poor access to water that lies outside the range for the control group. Admittedly this common support requirement results in dropping many observations (see below), which raises the problem of whether effects measured via PSM are representative of the broader population. However, if our results using regression analysis on the whole sample are similar to results for PSM we will be reassured. A further factor important for matching (Heckman et al, 1997) is that both treated and controls reside in the same narrowly-defined local labour markets, in our case, rural villages. 
We make the propensity score logit for poor access to water depend upon government investment in water construction in the individual's village (water plant), and all 128 village dummies. We also include a broad set of further variables (see Caliendo and Kopeinig, 2008) on individual and household level characteristics relevant to wage work participation. Then, to match treatment and control groups we use four common matching techniques: Nearest neighbour, Radius, Kernel and Stratification matching. Each has its own advantages and disadvantages (see Becker and Ichino, 2002), and we report outcomes for all.

\section{The Results}

Regression results. First, we estimate an IV probit model for women and men separately to test the exogeneity of the poor access to water variable for wage work participation models. Table 3 shows that the impact of poor access to water is only significant for women. It is also quantitatively large, -0.50 for the pre-menopause group. In fact, for all groups in Table 3, the Wald test indicates that poor water access is exogenous, so we will proceed on that basis.

Table 4 then presents probits for various groups. Most models include all 128 village fixed effects, though samples for models (3) and (5) are too small, and so only 36 county effects incorporated. In the first column, results for a sample pooling all women are given which shows explicitly the separate effects of poor access to water, menopause, and their interaction. As can be seen, the cross-product is significant, and it is large, -0.69 . The effect of poor water access alone is $-0.38(=-0.69+0.31)$, somewhat smaller than the IV result shown in Table $3(-0.46)$ indicating some downward bias results from the ordinary probit approach. In columns (2) and (3), results are given for the pre- and post-menopause groups separately, and since crossproducts are not needed, average marginal effects (AMEs) can be calculated. Two probit models are also estimated for men aged 50 or younger and over 45 for comparison purposes (the age spans chosen generally match the age spans of pre- and post-menopause women in the sample).

As can be seen from Table 4, the effect of poor access to water is only significant for women pre-menopause, while it is virtually zero for post-menopause women and men after controlling for other factors. The AME of poor access to water (column 2) implies that poor access to water reduces the probability of wage work participation for women pre-menopause by 6 percentage points, holding other things equal.

It is interesting that poor water access has so little effect on men's wage work participation, ceteris paribus, despite its strong association with participation in Table 2. However, we are controlling for the village off-farm work rate, and also village fixed effects, all of which pick up local opportunities for wage work, and are correlated with poor water access. Table 5 shows that if we exclude village controls (the village fixed effects, and village off-farm work rates) from the probits, the poor access to water variable becomes significant for men. We conclude that while local opportunities for wage work play an important role for all groups, this fact does not overturn our hypothesis that poor water access plays an independent role negatively impacting pre-menopause women. 
Most other variables have the signs expected. Having children under 6 in the household has a particular negative impact (-0.21) on post-menopause women's wage work participation while it has virtually no impact for other groups. This finding relates to the low wage work participation for this group (Table 2), and chimes in with the fact that in rural China, older women often look after young children to support younger women and men at work (Entwissle and Chen, 2002)

Finally, it must be emphasised that village dummies are included in the model to pick up unobserved village fixed effects - e.g. culture and remote geography. While some village dummies have to be dropped due to collinearities in the regression, many of the remaining villages possess significant fixed effects, a fact that shows the importance of controlling at the village level.

PSM results. The covariates included in the logit models to derive the propensity scores are generally the same with those in IV probit models in Table 3 (first stage), apart from the fact that now 128 village dummies are included instead of 36 county dummies. The impacts of covariates however remain generally the same and therefore the results are not given. The logit model is estimated for men and women (premenopause) separately in order to enable covariate balancing before matching. The most important determinant of poor access to water is government investment in village water construction (water plant), plus the village fixed effects.

The results of the covariate mean comparisons between treated and control groups of women are shown in the Table 6. (Results are not given for men as they show the same pattern as for women.). The first row gives the lower bound of the probability of having poor access to water for each block. For example, in block 2, the probability of having access to poor water varies from 0.2 to (maximum) 0.39 . The $t-$ test results show that the mean values of selected covariates within each block are not different between the treatment and control groups - in fact, there is not a single significant difference (For other covariates not shown in the table, the means are also found to be not different.)

Table 7 gives the estimated ATT results using the four matching techniques. The techniques show a similar negative effect of poor access to water on wage work participation of women. No impact is found for men. The size of the impact varies between -0.09 and -0.13 depending upon technique. Interestingly, this effect is greater than the -0.06 average marginal effect estimated from the regressions, further indicating that some downward bias results from the ordinary probit approach.

An impact of around -0.10 is large, considering the unconditional mean difference of wage work participation between pre-menopause women with good and poor access to water is about 23 percentage points (Table 1). In other words, about $40 \%(=0.10 / 0.23)$ of the disadvantage in wage work participation that women in poor access to water households suffer is really due to poor access to water. The remainder is due to factors such as lack of village development which are associated with poor access to water. For men, poor access to water has no causal effect on wage work participation. 


\section{Conclusions}

In this study, we investigate the impact of poor access to water on wage work participation in rural China. This study hypothesises that women pre-menopause face higher costs of participation and achieve lower productivity when access to water is poor (holding other things equal), and therefore have lower rate of wage work participation. We use CHNS data for 1993 to test the hypothesis. In this dataset, about half of the respondents do not have access to improved water, and also a large number of respondents are not involved in any type of wage work. Most importantly, there is specific information about women's menopause status.

We use both regression analysis and PSM methods to test the hypothesis. Both approaches yield supportive results. Women pre-menopause are found to be especially affected by poor access to water, that is, their probability of participating in wage work is about 10 percentage points lower than their peers with good access to water controlling for other confounding factors. For men, poor access to water per se has no causal impact on wage work participation. Therefore, a major benefit of policies to improve water supplies may not be the obvious household or industrial benefit, but rather an unseen benefit, the improvement in the working position of women. While much of these benefits have already been gained in China which has made good progress in raising access to water, the results should be relevant to other areas of the developing world. 
Figure 1: Women's share in wage work and access to sanitation facilities, developing countries in 2000

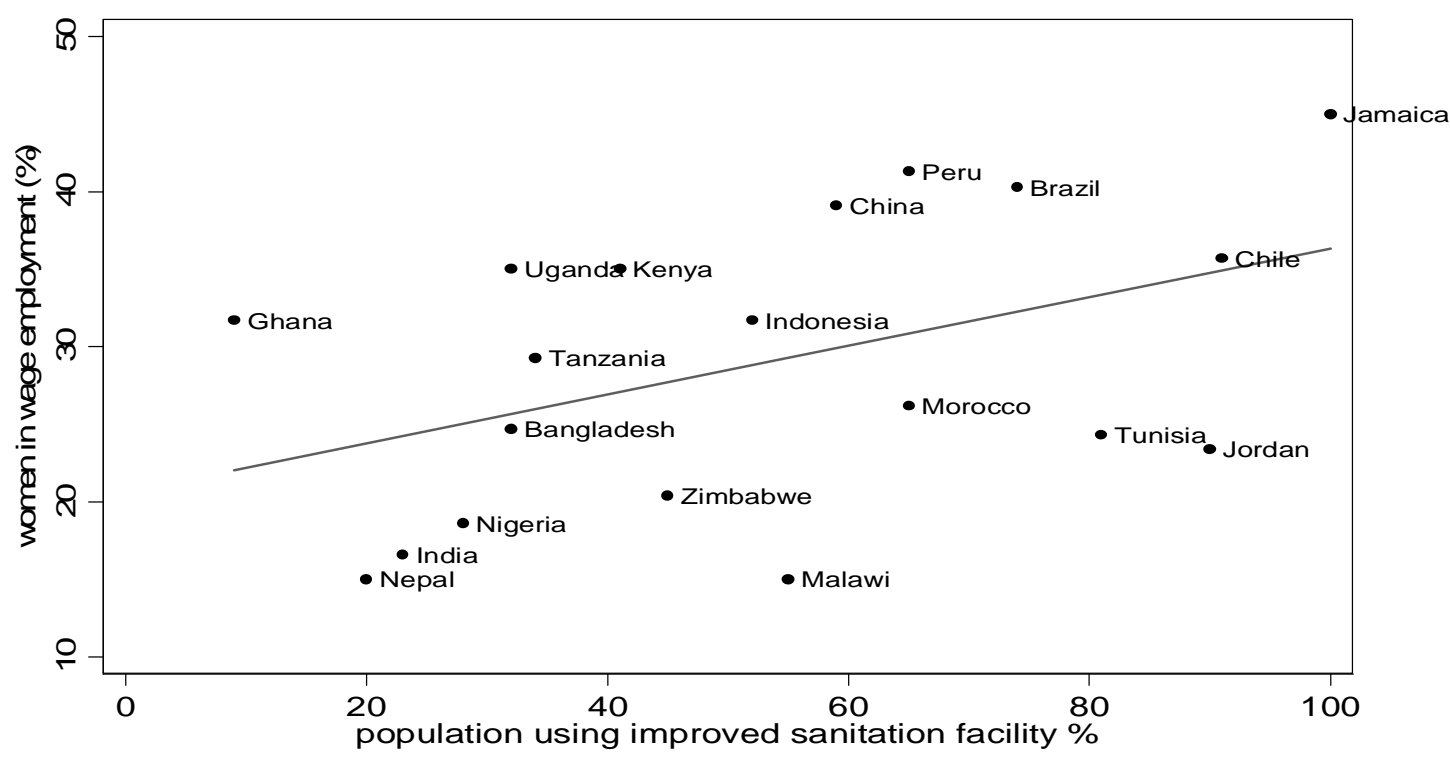

Source: UN (2009)

Figure 2: Trends in household access to water

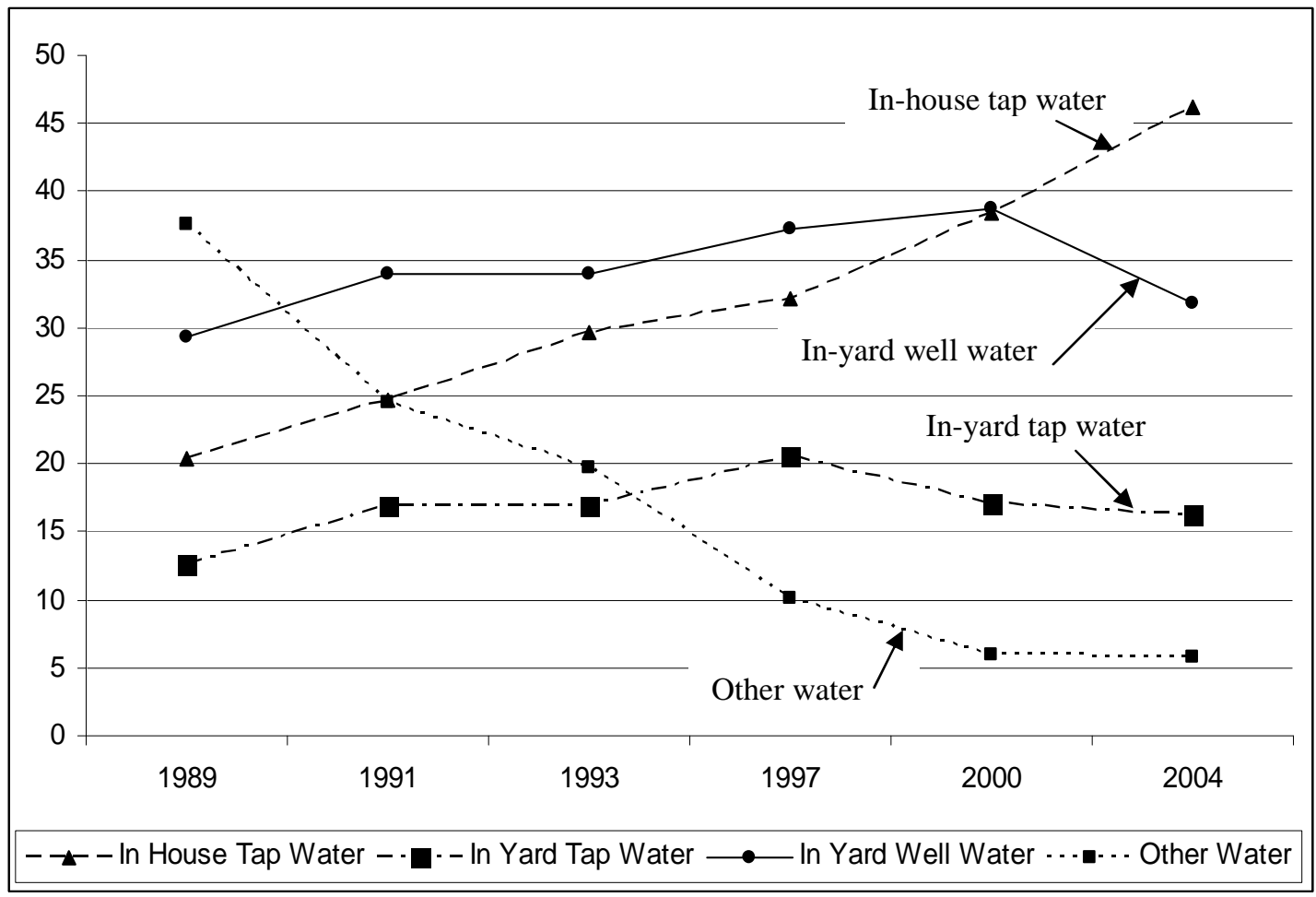

Source: CHNS 1989 - 2004. 
Table 1: Means and standard deviations of the major variables in wage work participation model, 1993

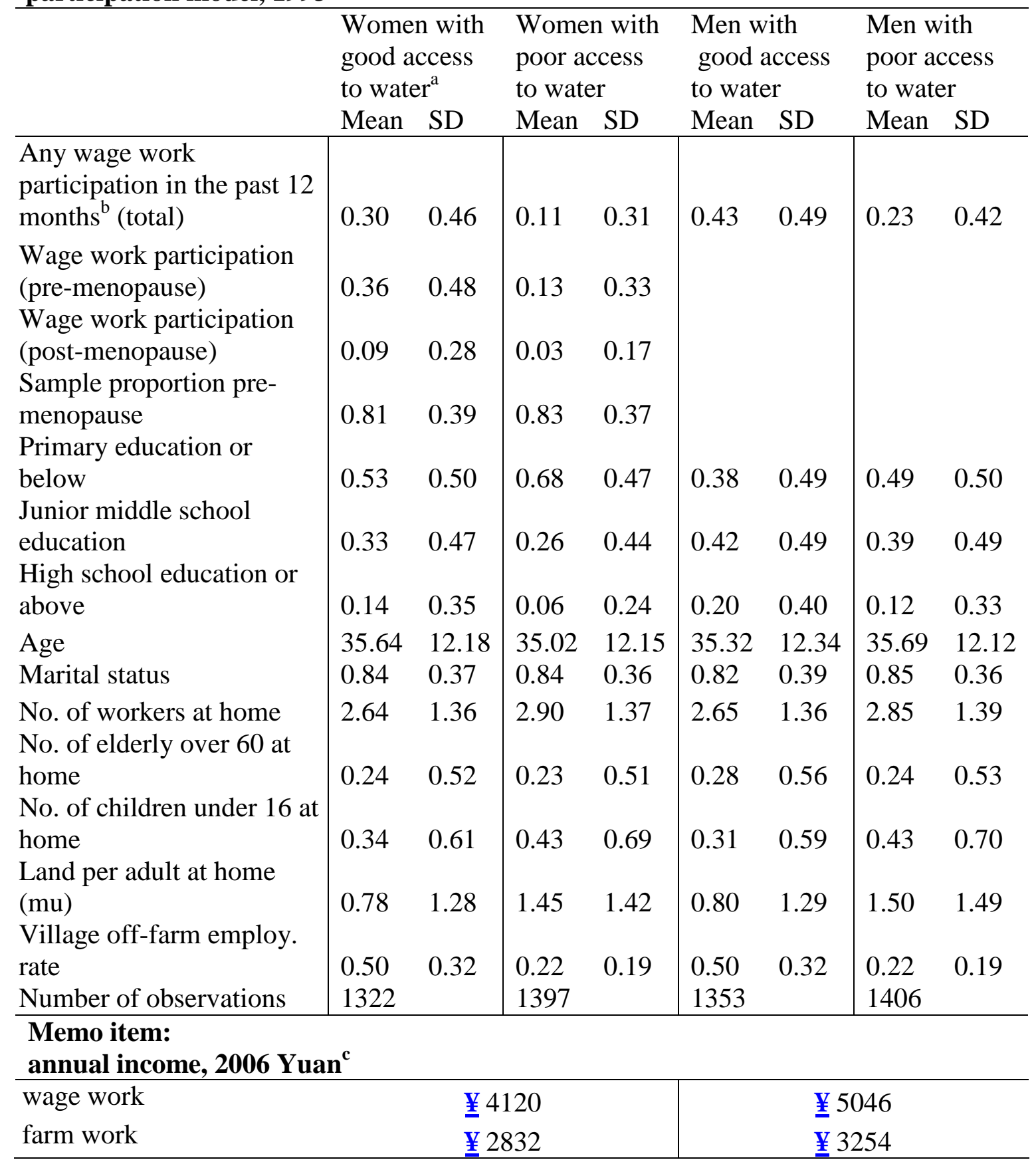

Note: The data are from the CHNS 1993.

${ }^{\mathrm{a}}$ Good access to water is defined as having tap water at home or in the courtyard.

${ }^{b}$ The village off-farm employment rate is the proportion of people involved in offfarm wage work plus people in self employment.

${ }^{\mathrm{c}}$ Individual income values are calculated in the CHNS survey not as a simple division of household income, but by adding up each individual's income from seven sources: business, farming, fishing, gardening, livestock, non-retirement wages and retirement income. The individual's hours worked in household businesses are used to estimate his/her income from that source where necessary. 
Table 2: Differences-in-Differences estimate of poor access to water on wage work participation, pre- and post-menopause

\begin{tabular}{l|l|l|l}
\hline & $\begin{array}{l}\text { Good access to } \\
\text { Water }\end{array}$ & $\begin{array}{l}\text { Poor access to } \\
\text { water }\end{array}$ & Difference \\
\hline Post-menopause & 0.09 & 0.03 & $0.06^{* *}$ \\
Pre-menopause & 0.36 & $(0.012,217)$ & $(0.023)$ \\
& $(0.015,982)$ & 0.13 & $0.23^{* * *}$ \\
& $(0.010,1059)$ & $(0.018)$ \\
& $\begin{array}{l}\text { Difference-in- } \\
\text { Difference }\end{array}$ & $\begin{array}{l}-0.17 * * * \\
(0.042)\end{array}$ \\
\hline
\end{tabular}

Memo item: Men $16-60$

\begin{tabular}{l|l|l|l}
\hline 50 or older & 0.39 & 0.19 & $0.20 * * *$ \\
49 or younger & $(0.026,356)$ & $(0.021,357)$ & $(0.033)$ \\
& 0.44 & 0.25 & $0.19 * * *$ \\
& $(0.015,1165)$ & $(0.013,1180)$ & $(0.019)$ \\
\hline
\end{tabular}

Notes: Good access to water refers to tap water. Standard errors of estimate and sample sizes are reported in parentheses. 
Table 3: The effect of access to water on wage work participation - instrumental variables results (IV)

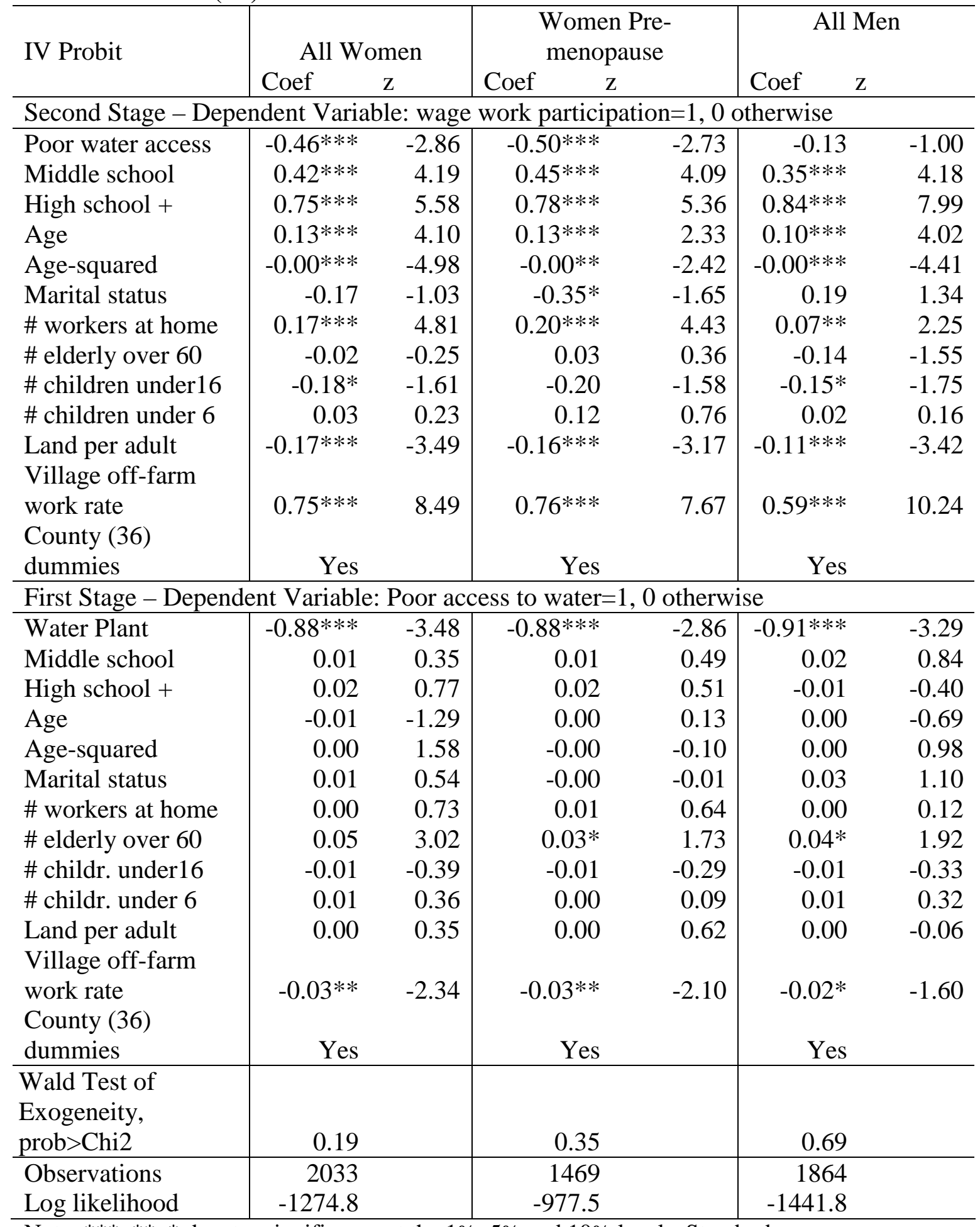

Note: $* * *, * *, *$ denotes significance at the $1 \%, 5 \%$ and $10 \%$ levels. Standard errors are adjusted for the county clusters. The inclusion of village dummies is not possible for IV probit due to non-concavity, but they are included in the main probit models in Table 4 . The impact of poor access to water is insignificant for women post-menopause in a separate IV probit model (results not shown, but similar results are given in Table 4). 
Table 4: Probit estimates of effects of access to water and menopause on wage work participation

(Dependent variable: wage work participation $=1,0$ otherwise)

\begin{tabular}{|c|c|c|c|c|c|}
\hline & $\begin{array}{c}\text { Women } \\
\text { All } \\
(1)^{\mathrm{a}}\end{array}$ & $\begin{array}{c}\text { Women } \\
\text { Pre- } \\
\text { menopause } \\
(2) \\
\end{array}$ & $\begin{array}{c}\text { Women } \\
\text { Post- } \\
\text { Menopause } \\
(3)\end{array}$ & $\begin{array}{c}\text { Men } \\
50 \text { or } \\
\text { younger } \\
(4)\end{array}$ & $\begin{array}{c}\text { Men } \\
45 \text { or } \\
\text { older } \\
(5)\end{array}$ \\
\hline & $\begin{array}{l}\text { Probit } \\
\text { Coef. }\end{array}$ & AME & AME & AME & AME \\
\hline $\begin{array}{l}\text { Poor water } \\
\text { access }=1 \text { (1) }\end{array}$ & 0.31 & $-0.06^{*}$ & 0.06 & 0.03 & 0.02 \\
\hline $\begin{array}{l}\text { Pre-menopause }=1 \\
\text { (2) }\end{array}$ & 0.51 & & & & \\
\hline $\begin{array}{l}\text { Cross-product (1) } \times \\
\text { (2) }\end{array}$ & $-0.69 * *$ & & & & \\
\hline Middle school & 0.37 & $0.10 * * *$ & -0.01 & $0.09 * * *$ & $0.08 * *$ \\
\hline $\begin{array}{l}\text { High } \\
\text { school + }\end{array}$ & 0.04 & $0.20 * * *$ & 0.07 & $0.23 * * *$ & $0.18 * * *$ \\
\hline Age & $0.12 * * *$ & $0.03 * * *$ & $0.04 * *$ & $0.02 * *$ & -0.04 \\
\hline Age-squared & $-0.0 * * *$ & $-0.0 * * *$ & $-0.0 * * *$ & $-0.00 * *$ & 0 \\
\hline Marital status & -0.02 & $-0.07 * *$ & 0.04 & $0.13^{* * *}$ & $0.08 *$ \\
\hline \# workers at home & 0.15 & $0.05 * * *$ & 0.01 & $0.02 * *$ & 0.01 \\
\hline \# elderly over 60 & -0.16 & 0.01 & -0.04 & -0.03 & -0.04 \\
\hline \# children under 16 & 0.34 & $-0.04 * *$ & $0.15^{*}$ & $-0.04 * *$ & 0.01 \\
\hline \# children under 6 & -0.39 & 0.02 & $-0.21 * *$ & 0 & -0.05 \\
\hline Land per adult & -0.25 & -0.03 & $-0.07 *$ & $-0.02 * *$ & -0.01 \\
\hline $\begin{array}{l}\text { Village off-farm } \\
\text { work rate }\end{array}$ & $0.28 * *$ & $0.16^{* * *}$ & $0.22 * * *$ & $0.14 * * *$ & 0.17 \\
\hline 128 village dummies & Yes & Yes & $\mathrm{Yes}^{\mathrm{b}}$ & Yes & Yes $^{\mathrm{b}}$ \\
\hline Observations & 1410 & 1086 & 184 & 1339 & 423 \\
\hline Pseudo R2 & 0.36 & 0.33 & 0.27 & 0.28 & 0.34 \\
\hline Log Likelihood & -521.1 & -445.8 & -55.9 & -617.8 & -109.6 \\
\hline
\end{tabular}

Note: $* * *, * *, *$ denotes significance at the $1 \%, 5 \%$ and $10 \%$ levels. AME denotes Average Marginal Effect (Bartus, 2005). Standard errors are adjusted for the village clusters.

${ }^{a}$ Model (1) includes cross products of menstrual cycle with other explanatory variables, but not with village dummies..

${ }^{\mathrm{b}} 36$ County dummies are used in Models (3) and (5) due to small sample size. 
Table 5: Sensitivity tests - excluding village controls

Probit estimates, Dependent variable: wage work participation $=1,0$ otherwise Coefficients on poor access to water variable

\begin{tabular}{lcccc}
\hline & $\begin{array}{c}\text { Women } \\
\text { Pre- } \\
\text { menopause }\end{array}$ & $\begin{array}{c}\text { Women } \\
\text { Post- } \\
\text { Menopause }\end{array}$ & $\begin{array}{c}\text { Men } \\
50 \text { or } \\
\text { younger }\end{array}$ & 45 or older \\
\cline { 2 - 5 } & AME & AME & AME & AME \\
\hline $\begin{array}{l}\text { Full model, Table } 4 \\
\text { repeated }\end{array}$ & $-0.06^{*}$ & 0.06 & 0.03 & 0.02 \\
\hline $\begin{array}{l}\text { Excluding village/county } \\
\text { fixed effects }\end{array}$ & $-0.05 * * *$ & 0.03 & 0.00 & 0.01 \\
$\begin{array}{l}\text { Excluding village off- } \\
\text { farm work rate }\end{array}$ & $-0.09 *$ & -0.02 & -0.004 & $-0.07 * * *$ \\
$\begin{array}{l}\text { Excluding both village } \\
\text { fixed effects and off- } \\
\text { farm work rate }\end{array}$ & $-0.10 * * *$ & -0.02 & $-0.07 * * *$ & $-0.15 * * *$ \\
$* * * * * *$ denotes significance at the $1 \%, 5 \%$ and $10 \%$ levels. & & \\
\hline
\end{tabular}

Note: the models here control for all variables shown in Table 4, except the village variables as detailed above. 
Table 6: Meeting the balancing requirement: Comparing selected covariate means for the matched samples (women - pre-menopause)

\begin{tabular}{|c|c|c|c|c|c|c|c|}
\hline & Block 1 & Block 2 & Block 3 & Block 4 & Block 5 & Block 6 \\
\hline \multicolumn{2}{|c|}{$\begin{array}{l}\text { Prop. Scores } \\
\text { - lower } \\
\text { bound }^{\mathrm{a}}\end{array}$} & 0.02 & 0.2 & 0.4 & 0.6 & 0.8 & 0.9 \\
\hline \multicolumn{2}{|l|}{ Obs. $^{b}$} & $\begin{array}{l}\mathrm{C}=116 \\
\mathrm{~T}=12\end{array}$ & $\begin{array}{l}\mathrm{C}=42 \\
\mathrm{~T}=16\end{array}$ & $\begin{array}{l}\mathrm{C}=26 \\
\mathrm{~T}=38\end{array}$ & $\begin{array}{l}\mathrm{C}=51 \\
\mathrm{~T}=110\end{array}$ & $\begin{array}{l}\mathrm{C}=21 \\
\mathrm{~T}=111\end{array}$ & $\begin{array}{l}\mathrm{C}=7 \\
\mathrm{~T}=123\end{array}$ \\
\hline $\begin{array}{l}\text { Middle } \\
\text { school }\end{array}$ & $\mathrm{C}$ & $\begin{array}{l}0.35 \\
(0.48) \\
0.33 \\
(0.49) \\
0.14 \\
\end{array}$ & $\begin{array}{l}0.36 \\
(0.48) \\
0.44 \\
(0.51) \\
-0.56 \\
\end{array}$ & $\begin{array}{l}0.35 \\
(0.49) \\
0.29 \\
(0.46) \\
0.49 \\
\end{array}$ & $\begin{array}{l}0.24 \\
(0.42) \\
0.34 \\
(0.47) \\
-1.29 \\
\end{array}$ & $\begin{array}{l}0.43 \\
(0.50) \\
0.32 \\
(0.47) \\
0.97 \\
\end{array}$ & $\begin{array}{l}0.57 \\
(0.52) \\
0.36 \\
(0.48) \\
1.12 \\
\end{array}$ \\
\hline Age & $\mathrm{C}$ & $\begin{array}{l}32.4 \\
(9.5) \\
31.3 \\
(9.0) \\
0.35\end{array}$ & $\begin{array}{l}33.1 \\
(8.5) \\
30.2 \\
(9.1) \\
1.27\end{array}$ & $\begin{array}{l}33.1 \\
(8.7) \\
34.3 \\
(8.7) \\
-0.61 \\
\end{array}$ & $\begin{array}{l}32.7 \\
(8.4) \\
33.5 \\
(7.9) \\
-0.58\end{array}$ & $\begin{array}{l}33.2 \\
(8.8) \\
31.8 \\
(8.0) \\
0.71 \\
\end{array}$ & $\begin{array}{l}30.7 \\
(4.4) \\
32.2 \\
(8.9) \\
-0.31 \\
\end{array}$ \\
\hline $\begin{array}{l}\text { Marital } \\
\text { status }\end{array}$ & $\mathrm{C}$ & $\begin{array}{l}0.82 \\
(0.38) \\
0.70 \\
(0.48) \\
0.93 \\
\end{array}$ & $\begin{array}{l}0.83 \\
(0.38) \\
0.77 \\
(0.43) \\
0.56 \\
\end{array}$ & $\begin{array}{l}0.86 \\
(0.36) \\
0.85 \\
(0.36) \\
0.11 \\
\end{array}$ & $\begin{array}{l}0.86 \\
(0.35) \\
0.89 \\
(0.31) \\
-0.55 \\
\end{array}$ & $\begin{array}{l}0.80 \\
(0.41) \\
0.89 \\
(0.32) \\
-1.24 \\
\end{array}$ & $\begin{array}{l}1.00 \\
(0.00) \\
0.87 \\
(0.34) \\
1.08 \\
\end{array}$ \\
\hline $\begin{array}{l}\text { Children } \\
\text { under } 16\end{array}$ & $\mathrm{C}$ & $\begin{array}{l}0.48 \\
(0.71) \\
0.70 \\
(0.82) \\
-0.93 \\
\end{array}$ & $\begin{array}{l}0.38 \\
(0.56) \\
0.28 \\
(0.46) \\
0.68 \\
\end{array}$ & $\begin{array}{l}0.29 \\
(0.46) \\
0.45 \\
(0.75) \\
-1.00 \\
\end{array}$ & $\begin{array}{l}0.47 \\
(0.73) \\
0.39 \\
(0.68) \\
0.68\end{array}$ & $\begin{array}{l}0.50 \\
(0.69) \\
0.57 \\
(0.71) \\
-0.41 \\
\end{array}$ & $\begin{array}{l}0.63 \\
(0.74) \\
0.53 \\
(0.74) \\
0.37 \\
\end{array}$ \\
\hline $\begin{array}{l}\text { Land per } \\
\text { adult }\end{array}$ & $\mathrm{C}$ & $\begin{array}{l}1.31 \\
(1.83) \\
1.52 \\
(2.77) \\
-0.33 \\
\end{array}$ & $\begin{array}{l}0.88 \\
(1.50) \\
0.72 \\
(0.71) \\
0.43 \\
\end{array}$ & $\begin{array}{l}0.87 \\
(0.51) \\
1.17 \\
(1.99) \\
-0.78 \\
\end{array}$ & $\begin{array}{l}0.67 \\
(0.72) \\
0.84 \\
(0.79) \\
-1.30 \\
\end{array}$ & $\begin{array}{l}2.27 \\
(3.86) \\
1.61 \\
(1.94) \\
1.19 \\
\end{array}$ & $\begin{array}{l}1.07 \\
(0.72) \\
1.59 \\
(1.83) \\
-0.80 \\
\end{array}$ \\
\hline $\begin{array}{l}\text { Village } \\
\text { off-farm } \\
\text { work rate }\end{array}$ & $\mathrm{C}$ & $\begin{array}{l}0.35 \\
(0.27) \\
0.37 \\
(0.30) \\
-0.22 \\
\end{array}$ & $\begin{array}{l}0.36 \\
(0.33) \\
0.37 \\
(0.35) \\
-0.11 \\
\end{array}$ & $\begin{array}{l}0.20 \\
(0.12) \\
0.25 \\
(0.19) \\
-1.23 \\
\end{array}$ & $\begin{array}{l}0.44 \\
(0.17) \\
0.42 \\
(0.17) \\
0.69 \\
\end{array}$ & $\begin{array}{l}0.20 \\
(0.11) \\
0.24 \\
(0.14) \\
-1.22 \\
\end{array}$ & $\begin{array}{l}0.23 \\
(0.25) \\
0.21 \\
(0.22) \\
0.25 \\
\end{array}$ \\
\hline $\begin{array}{l}\text { \# workers } \\
\text { at home }\end{array}$ & $\mathrm{C}$ & $\begin{array}{l}.49 \\
(1.25) \\
2.30 \\
(1.49) \\
0.45\end{array}$ & $\begin{array}{l}2.67 \\
(1.34) \\
2.39 \\
(0.77) \\
0.84\end{array}$ & $\begin{array}{l}2.5 \\
(1.1) \\
2.3 \\
(0.93) \\
0.81\end{array}$ & $\begin{array}{l}2.33 \\
(1.21) \\
2.39 \\
(1.32) \\
-0.28\end{array}$ & $\begin{array}{l}2.4 \\
(1.14) \\
2.43 \\
(1.05) \\
-0.12\end{array}$ & $\begin{array}{l}2.25 \\
(0.46) \\
2.78 \\
(1.65) \\
-0.90\end{array}$ \\
\hline
\end{tabular}

$* * *, * *, *$ denotes significance at the $1 \%, 5 \%$ and $10 \%$ levels. Standard deviations are in parentheses.

Note: ${ }^{a}$ The first row gives the lower bound of the probability of having poor access to water for each block.

${ }^{\mathrm{b}} \mathrm{T}$ denotes treated, total treated obs. $=410 ; \mathrm{C}$ denotes control, total control obs. $=263$ 
Table 7: Average Treatment (poor access to water) Effects

\begin{tabular}{lcc}
\hline & $\begin{array}{c}\text { Women } \\
\text { (Pre-Menopause) }\end{array}$ & $\begin{array}{c}\text { Men } \\
\text { (aged 50 or younger) }\end{array}$ \\
\hline $\begin{array}{l}\text { Nearest Neighbour } \\
\text { Matching }\end{array}$ & $-0.13 *(-1.65)$ & $0.02(0.29)$ \\
Radius Matching & $\mathrm{T}=410 \mathrm{C}=107$ & $\mathrm{~T}=422 \mathrm{C}=105$ \\
(radius=0.01) & $-0.09(-1.54)$ & $0.03(0.51)$ \\
Kernel Matching & $\mathrm{T}=398 \mathrm{C}=231$ & $0.04(0.61)$ \\
& $-0.09 *(-1.66)$ & $\mathrm{T}=422 \mathrm{C}=235$ \\
Stratified Matching & $\mathrm{T}=410 \mathrm{C}=263$ & $0.04(0.67)$ \\
& $-0.10 *(-1.76)$ & $\mathrm{T}=422 \mathrm{C}=235$ \\
\hline
\end{tabular}

Note: $\mathrm{T}=$ Treated (poor access to water); $\mathrm{C}=$ Control. $\mathrm{t}$-statistics are in parentheses and are calculated using bootstrapped 


\section{REFERENCES:}

Ahmed, R., and Yesmin, K. (2008) "Menstrual Hygiene: Breaking the Silence", in Wateraid, Beyond Construction - A collection of case studies from sanitation and hygiene promotion practitioners in South Asia, London: Water Aid, 2009.

Angrist, J., D. and Pischke, J-S (2009) Mostly Harmless Econometrics, Princeton University Press, Princeton and Oxford

Bharadwaj, S., and Archana, P. (2004) "Menstrual Hygien and Management in Developing Countries: Taking Stock", Mumbai: Junction Social.

Bartus, T. (2005) "Estimation of Marginal Effects Using margeff", The Stata Journal, 5 (3): pp. 309-329

Becker, S., and A. Ichino (2002) "Estimation of Average Treatment Effects Based on Propensity Scores," The Stata Journal 2 (4): pp. 358-377

Benjamin, D., Brandt, 1., Glewwe, P., and Li, G. (2000) "Markets, Human Capital and Inequality: Evidence from Rural China”, University of Michigan Business School Working Paper No.298.

Bryson A., Dorsett, R. and Purdon, S. (2002). "The Use of Propensity Score Matching in the Evaluation of Active Labour Market Policies", Working Paper Number 4, London: Department of Work and Pensions.

Burns N., Scholzman K., and Verba S. (1997). "The Public Consequences of Private Inequality: Family Life and Citizen Participation", The American Political Science Review, 91 (2): 373-89.

Burrows, G., Acton, J., and Maunder, T. (2004) Water and Sanitation: the Education Drain, London: Wateraid, http://www.wateraid.org/other/startdownload.asp?DocumentID=113

Caliendo, M.and Kopeinig, S. (2008) "Some Practical Guidance for the Implementation of Propensity Score Matching", Journal of Economic Surveys, 22: 31-72.

Cameron, A., C. and Trivedi, P., K. (2005) Microeconometrics: Methods and Applications, Cambridge, New York

Cameron, A., C. and Trivedi, P., K. (2009) Microeconometrics Using Stata, Stata Press, Texas

Chawla, A., Swindle, R., Long, S., Kennedy S., and Steinfeld, B. (2002). "Premenstrual Dysphoric Disorder - Is There an Economic Burden of Illness?", Medical Care 40 (11): 1101-12.

Chhibber, P. (2002). "Why Are Some Women Politically Active? The Household, Public Space and Political Participation in India", International Journal of Comparative Sociology, 43: 409-29.

CHNS (2009) China Health and Nutrition Survey, Chapel Hill, North Carolina: Carolina Population Center, http://www.cpc.unc.edu/projects/china

Dean, B., and Borenstein, J. (2004). "A Prospective Assessment Investigating the Relationship between Work Productivity and Impairment with Premenstrual Syndrome", Journal of Occupational and Environmental Medicine, 46 (7): 64956.

Deuster P., Adera T., and South-Paul J. (1999). "Biological, Social and Behavioural Factors Associated with Premenstrual Syndrome", Archives of Family Medicine, 8: 122-28. 
Entwisle, B., and Chen, F-N (2002) "Work Patterns Following a Birth in Urban and Rural China: A Longitudinal Study", European Journal of Population, 18: pp.99-119

Field, E. and Arbus, A. (2008) "Early Marriage, Age of Menarche and Female Schooling Attainment in Bangladesh", Journal of Political Economy, 116(5): 881-930.

Flabbi, L., and Ichino, A. (2001) "Productivity, Seniority and Wages: New Evidence from Personnel Data”, Labour Economics, 8: pp 359-387.

Frolich, M. (2008). "Parametric and Nonparametric Regression in the Presence of Endogenous Control Variables", International Statistical Review, 76: 214-227.

Galiani S., Gonzalez-Rozada M., and Schargrodsky E. (2009) "Water Expansions in Shantytowns: Health and Savings", Economica 76: 607-22.

Galiani S., Gertler P., and Schargrodsky E. (2005). "Water for Life: The Impact of the Privatization of Water Services on Child Mortality", Journal of Political Economy, 113: 83-120.

Glaeser, E., Ponzetto G., and Shleifer, A. (2007) "Why Does Democracy Need Education?", Journal of Economic Growth, 12: 77-99.

Goldin C., and Katz L. (2002). "The Power of the Pill: Oral Contraceptives and Women's Career and Marriage Decisions”, Journal of Political Economy, 110 (4): 730-70.

Guo, S-Y, and Fraser, M., W. (2009) Propensity Score Matching, Sage, London

Hare, D. (1999) “Women's Economic Status in Rural China: Household Contributions to Male-Female Disparities in the Wage-Labour Market", World Development, 27(6): pp 1011-1029

Heckman, J., Ichimura, H., and Todd, P. (1997) "Matching as a Econometric Evaluation Estimator: Evidence from Evaluating a Job Training Programme", Review of Economic Studies, 64: 605-54.

Ichino, A. and Moretti, E. (2009) "Biological Gender Differences, Absenteeism and the Earning Gap", American Economic Journal: Applied Economics, 1(1): pp. $183-218$

Imbens, G. and Wooldridge, J. (2009) "Recent Developments in the Econometrics of Program Evaluation", Journal of Economic Literature, 47: 5-86.

Iversen T., and Rosenbluth, R. (2006). "The Political Economy of Gender: Explaining Cross-National Variation in the Gender Division of Labor and the Gender Voting Gap", American Journal of Political Science, 50 (1): 1-19.

Jacka, T. (1997) Women's Work in Rural China: Change and Continuity in an Era of Reform, Cambridge University Press, Cambridge

Jalan, J., and Ravallion, M (2003) "Does piped water reduce diarrhoea for children in rural India?", Journal of Econometrics, 112: pp153-173

Kirk, J. and Sommer, M. (2006) "Menstruation and Body Awareness: Critical Issues for Girls' Education”, EQUALS, 15: pp 4-5.

Maimaiti, Y. and Siebert, W. S. (2009) "The Gender Education Gap in China - The Power of Water", IZA Discussion Paper 4018

Mangyo E. (2008). "The Effect of Water Accessibility on Child Health in China", Journal of Health Economics 27: 1343-56.

Oster, E., and Thornton, R (2009) "Menstruation and Education in Nepal", NBER working paper, 14853.

Pearl, J. (2009). Causality, 2d edition, Cambridge: Cambridge University Press

Rosenbaum, P., and Rubin, D (1983) "The Central Role of the Propensity Score in Observational Studies for Causal Effects," Biometrika, 70, pp.41-55 
Sicular, T., and Zhao, Y-H (2004) "Earnings and Labour Mobility in Rural China: Implications for China's Accession to the WTO", In China and the WTO:

Accession, Policy Reform and Poverty Reduction Strategies (Ed: Bhattasali, D., Li, S-T, Martin, W), The World Bank, Oxford University Press, pp. 239-260

Song, L., and Appleton, S., and Knight, J., 2006, "Why Do Girls in Rural China Have Lower School Enrolment?” World Development, 34(9), 1639_1653

UN (2009) Millennium Development Goals Indicators Database, http://mdgs.un.org/unsd/mdg/Data.aspx

UNICEF (2009). Unicef and Education: Menstruating Girls, Aspen Design Summit, November 11-14, Aspen Colorado

Wateraid (2009). Beyond Construction - A collection of case studies from sanitation and hygiene promotion practitioners in South Asia, London: Water Aid

Wang G. (2007). "Testing the Impact of Gender Equality on Reproductive Health: An Analysis of Developing Countries", The Social Science Journal 44: 507-24.

Stewart F., Shields, W., and Hwang A. (2004). "Cairo Goals for Reproductive Health: Where Do We Stand at 10 Years?" Contraception 70: 1-2.

Yang, J. H. (2006) "Has the One-Child Policy Improved Adolescents' Educational Wellbeing in China?" _ CHNS discussion paper 2006.

Zhang, L-X, de Brauw, A., and Rozelle, S (2004) "China's Rural Labour Market Development and Its Gender Implications", China Economic Review, 15: pp. 230-247

Zhang, L-X, Huang J-K, and Rozelle, S. (2002) "Employment, Emerging Labour Markets and the Role of Education in Rural China", China Economic Review, 13: pp. 313-328 